\title{
Sustainable Thermal Insulation Biocomposites from Locally Available Hemp and Lime
}

\author{
Maris Sinka, Genadijs Sahmenko, \\ Riga Technical University
}

\begin{abstract}
The key focus of the presented research is on sustainable thermal insulation biocomposites which can be made from locally available hemp and lime. The main gains of the use of such material are given, with emphasis on $\mathrm{CO}_{2}$ reduction. In the first stage samples of an artificial hydraulic lime using three different limes and three hydraulic additives are created and tested, the one with the highest compressive strength (DL60 lime with $40 \%$ metakaolin addition) are chosen for further research. In the second stage three different density mixes with the chosen binder are created, optimal hemp/binder ratio is determined, as well as compressive strength and thermal conductivity. Results indicate that created mixtures have good potential as self-bearing thermal insulation material used in low-rise buildings.
\end{abstract}

Keywords -hempcrete, hydraulic lime, low-carbon, sustainable materials.

\section{INTRODUCTION}

Sustainable building materials are one of the most topical subjects today in building material industry due to the growing concerns about anthropogenic factor impact on $\mathrm{CO}_{2}$ levels in atmosphere and its correlation with global temperature rise [1]. Globally manufacture of building materials is responsible for about $10 \%$ of all $\mathrm{CO}_{2}$ emissions [2], which is the same in Latvia [3].

In more indirect way building materials are responsible for another source of $\mathrm{CO}_{2}$ emissions from energy consumed for building heating and cooling in the cases when building is made out of inefficient materials with high thermal conductivity values. Heating energy losses are even larger then material manufacture industry - together with electricity and water heating it generates $36 \%$ of all $\mathrm{CO}_{2}$ emissions in Latvia, $50 \%$ in UK [4], $45 \%$ Canada, $40 \%$ USA, and $20 \%$ in China [5].

Therefore, building material industry needs to give its solution to this problem. One of the ways to answer these challenges would be to perfect and promote the use of biocomposite materials. Along with other great properties, a lot less $\mathrm{CO}_{2}$ is created in manufacture process of these materials, because one of the two main components of the composite is made from biological ingredients, which has sequestered $\mathrm{CO}_{2}$ in the growing process. As to even more lower their carbon footprint, the binder usually used is low-carbon too - either lime or clay. And as these materials are considered sustainable, their thermal conductivity coefficient is low enough to be compatible with traditional building materials.

There are many different low carbon dioxide biocomposites, such as hemp-lime, hemp-clay [6], straw-clay [7]. One of biocomposites which is particularly interesting in Latvia, because it can be made using locally available resources, is hemp-lime self-bearing heat insulation material. Hemp shives and hydraulic lime are two main components of natural biocomposites. In Figure 1. biocomposite composition with three main $\mathrm{CO}_{2}$ flows can be seen, which represent most significant carbon dioxide emission and absorption processes in biocomposite manufacture.

Hemp shives are inner part of hemp stalk, by chemical composition it is very similar to wood-pulp as it contains a lot of lignin. It is considered a byproduct as the main purpose of hemp growing is obtainment of fiber and seeds. The chief market for hemp shives for now is their use as bedding material in horse stables, because of its outstanding moisture and smell absorption capabilities. It is due to this porous nature of hemp shives that it can be used as a filler in thermal insulating biocomposites, as it allows the material to have both great moisture regulating capabilities and low thermal conductivity.

Lime is an appropriate binder for biocomposites, because of its properties. First of all, it has a lot less embodied carbon in its manufacturing process as other binders, like concrete - for 1 ton of hydrated lime $337 \mathrm{~kg}$ of $\mathrm{CO}_{2}$ are created, for concrete $-819 \mathrm{~kg}$ [8]. Secondly, when lime hardens, it reabsorbs carbon dioxide that was released in burning process from limestone, through carbonization. And third of all, its water vapor permeability makes it fully compatible with hemp shives, to create a material with good moisture regulating properties.

Hydraulic lime can be made by mixing air lime with hydraulic additives, to make it stronger and more appropriate as a self-bearing biocomposite binder. Most important properties of hydraulic additives are high amorphous $\mathrm{SiO}_{2}$ amount and small particle size [walker]. Commonly used additives for lime are silica fume [9], metakaolin [10], fly-ash [11], various ground glass [12] and brick [9]. 


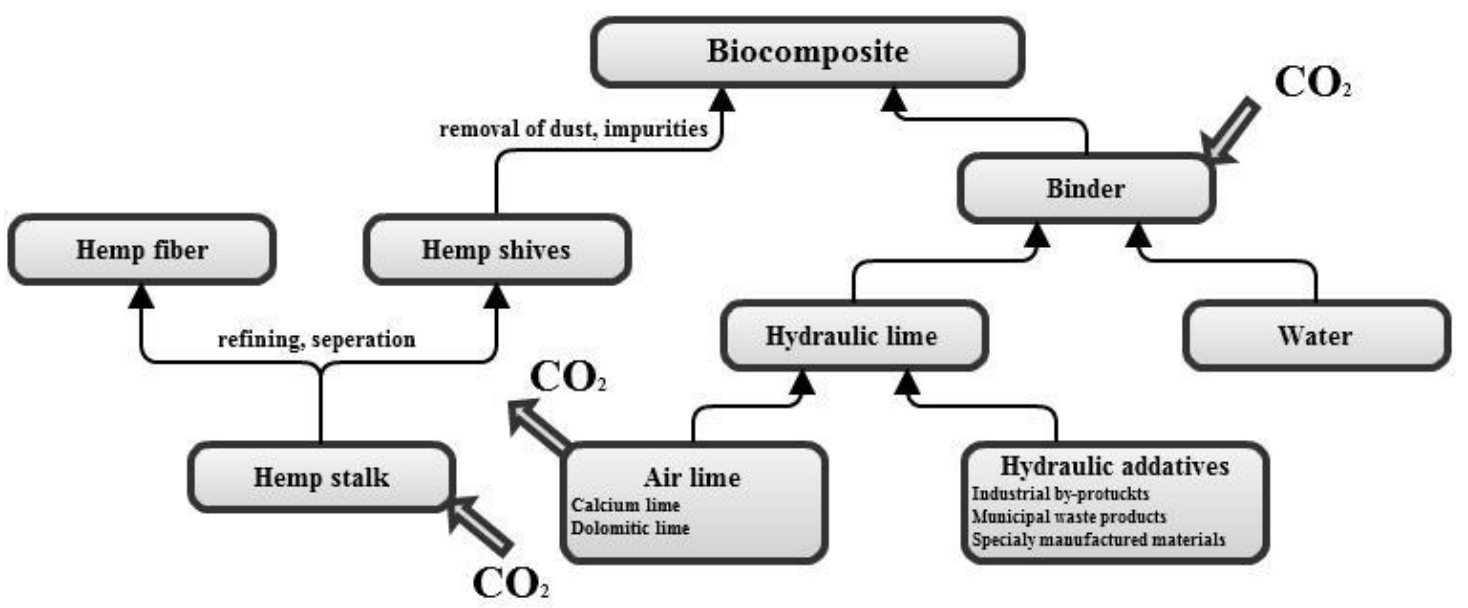

Fig. I. Composition of biocomposites with three main $\mathrm{CO}_{2}$ flows

As for total $\mathrm{CO}_{2}$ emitted by hemp-lime biocomposite, research shows that in fact this material absorbs, through growing of hemp stalk and carbonization of lime, more carbon dioxide than is emitted. Various researchers propose different amounts of $\mathrm{CO}_{2}$ sequestered in full life cycle of material in $1 \mathrm{~m}^{3}-4 \mathrm{~kg}$ [13], $108 \mathrm{~kg}$ [4], $120 \mathrm{~kg}$ [14]as they are using different calculation methods, but one thing is clear - biocomposite made of hemp-lime mix is carbon neutral or even negative.

The aim of this research first of all is to examine the effect of three hydraulic additives on compressive strength on various air limes, to compare it with previously known biocomposite binder strengths and to choose the most suitable for further research. Then it will be mixed with hemp shives to investigate thermal conductivity and compressive strength of heat insulating biocomposites made from locally available resources. Various binder proportions will be used to test the correlation between compressive strength, binder properties, density and thermal conductivity.

\section{MATERIALS AND METHODS}

\section{A. Material properties}

To find out the effect of lime content on formation of hydraulic compounds, three different commercially available air limes were used, their composition is given in Table I.

TABLE I

PROPERTIES OF USED LIMES

\begin{tabular}{|l|l|l|l|l|}
\hline Name & $\begin{array}{l}\text { CaO+MgO } \\
\text { content, \% }\end{array}$ & $\begin{array}{l}\text { Active } \\
\text { lime, } \%\end{array}$ & $\begin{array}{l}\text { Bulk } \\
\text { density, } \\
\mathrm{kg} / \mathrm{m}^{3}\end{array}$ & Color \\
\hline $\begin{array}{l}\text { Hydrated } \\
\text { lime CL90 }\end{array}$ & $\geq 90$ & $\geq 80$ & 627 & white \\
\hline $\begin{array}{l}\text { Hydrated } \\
\text { lime CL80 }\end{array}$ & $\geq 80$ & $\geq 65$ & 417 & white \\
\hline $\begin{array}{l}\text { Quicklime } \\
\text { DL60 }\end{array}$ & $\geq 60$ & $\mathrm{X}$ & 807 & grey \\
\hline
\end{tabular}

Three different pozzolanic additives were tested. First one - metakaolin which is obtained by burning kaolin clay at $800^{\circ} \mathrm{C}$. Other two are ground crushed bricks from building demolition waste recycling - one with fireproof capabilities, the other - hollow loadbearing brick.

Hemp shives were obtained as by-product of hempfiber manufacture. Bulk density of used hemp shives is $97 \mathrm{~kg} / \mathrm{m}^{3}$. Particle size distribution of hemp material can be seen in Table II and in Figure 1.

\section{B. Experimental methods}

To test the ability of hydraulic additions to react with lime $160 * 40 * 40$ prisms were made using oiled steel moulds. Mixing of specimens were done manually, water were added as necessary to ensure a constant plastic consistency of mortar, so no mechanical vibration tools were needed.

After casting in moulds, specimens were covered with polyethylene film, kept for 7 days, then demoulded, sprayed with water and again covered with film to ensure constant high relative humidity $(95 \pm 5 \%)$, with was measured with hygrometer.

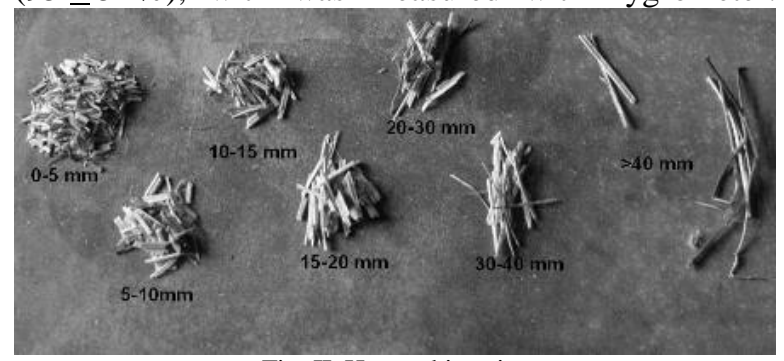

Fig. II. Hemp shive size

TABLE II

HEMP SHIVE GRANULOMETRY

\begin{tabular}{|l|c|c|c|c|c|c|c|}
\hline $\begin{array}{l}\text { Length, } \\
\mathrm{mm}\end{array}$ & $0-5$ & $5-10$ & $10-15$ & $15-20$ & $20-30$ & $30-40$ & $>40$ \\
\hline $\begin{array}{l}\% \text { of } \\
\text { mass }\end{array}$ & 27 & 15 & 14 & 19 & 13 & 8 & 4 \\
\hline
\end{tabular}


Compressive strength of the samples was measured after 28 days of curing, tolerance of force determination $\pm 1 \%$. The binder with highest performance was selected for furtherer tests.

During the experiment 3 different compositions of biocomposites were made. To test the influence of material density on thermal conductivity and compressive strength, various binder proportions were tested.

Drum mixer were used to mix the samples. First of all hemp shives were put in the mixer with half of the necessary amount of water and mixed for 3 minutes. Then the binder was added, mixed for 2 minutes, and after all - the rest of the water. Preparation continued until the binder was evenly distributed, which took 3-4 minutes. The mixed compositions were cast in oiled steel moulds with dimensions of $100 * 100 * 100 \mathrm{~mm}$ for compressive strength testing, and in $350 * 350 \mathrm{~mm}$ water-proof plywood moulds for thermal conductivity testing. Material were cast in three layers, moderately tamping each layer, polyethylene film were placed on top to prohibit fast drying of the samples, then a steel plate with weight on top of it all for even compaction.

The film and weight were removed after 3 days, specimens were demoulded after 7 days of curing. Hardening conditions were $20 \pm 2^{0} \mathrm{C}$ temperature and $55 \pm 10 \%$ relative humidity.

To assess material density, before tests specimens were weighted and their dimensions were measured.

Compressive tests were performed using universal testing machine Zwick Z100 (maximal applicable force $-100 \mathrm{kN}$ ). Pressure on specimens was applied in the same direction as compaction, by rate $10 \mathrm{~mm} / \mathrm{min}$, force - deformation diagram was recorded during the test. As biocomposites with relatively low compressive strength can exhibit relatively large deformations without noticeable breaking point, maximal compressive strength is measured at $10 \%$ deformation (in this case at $10 \mathrm{~mm}$ of absolute deformation).

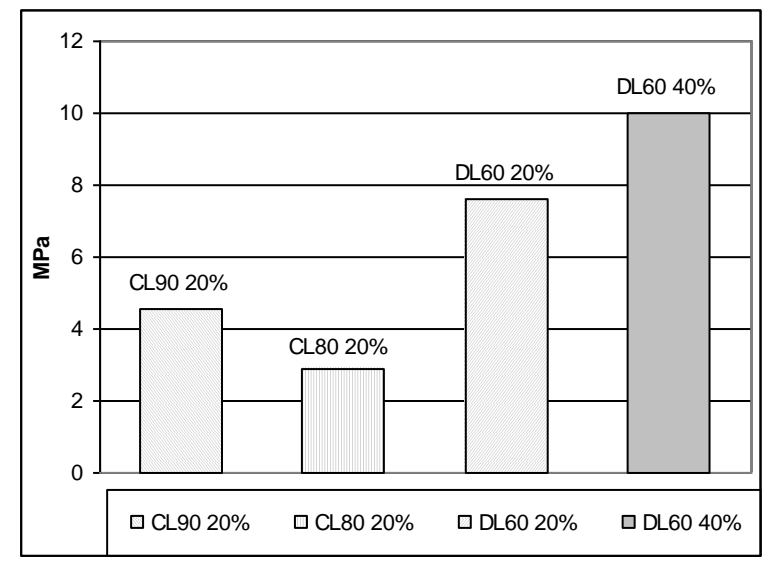

Fig. III. Compressive strength of various limes with metakaolin addition.

Thermal conductivity was determined using Fox 600 heat flow measuring device. Sample was fixed horizontally. During the test temperature of lower surface was $+20^{\circ} \mathrm{C}$ and $0^{\circ} \mathrm{C}$ of upper surface (mean temperature $+10^{\circ} \mathrm{C}$ ). Heat transmission coefficient was determined considering constant heat flow between two sides of sample.

\section{RESULTS AND DISCUSCTION}

A. Composition of Lime binders

The testing of binders were done in two stages. During the first stage optimal amount of metakaolin were determined in combination with most suitable lime. During the second stage two different ground brick additions were examined to clarify their hydraulic properties.

TABLE III

ARTIFICIAL HYDRAULIC LIME MIXES

\begin{tabular}{|l|c|c|c|c|c|c|c|c|}
\hline Sample name & Lime & Lime, g & Meta., g & Brick1, g & Brick2, g & Sand, g & Water, g & $\begin{array}{c}\text { Hydraulic } \\
\text { add., } \%\end{array}$ \\
\hline CL90 20\% & CL90 & 240 & 60 & 0 & 0 & 600 & 266 & $20.0 \%$ \\
\hline CL80 20\% & CL80 & 240 & 60 & 0 & 0 & 600 & 300 & $20.0 \%$ \\
\hline DL60 20\% & DL60 & 240 & 60 & 0 & 0 & 600 & 200 & $20.0 \%$ \\
\hline DL60 40\% & DL60 & 180 & 120 & 0 & 0 & 600 & 200 & $40.0 \%$ \\
\hline DL60 & DL60 & 300 & 0 & 0 & 0 & 600 & 200 & $0.0 \%$ \\
\hline $\begin{array}{l}\text { DL60 +10\% } \\
\text { meta +10\% } \\
\text { brick1 }\end{array}$ & DL60 & 240 & 30 & 30 & 0 & 600 & 200 & $20.0 \%$ \\
\hline $\begin{array}{l}\text { DL60+ + } \\
\text { 28.5\% brick1 }\end{array}$ & DL60 & 214.5 & 0 & 85.5 & 0 & 600 & 200 & $28.5 \%$ \\
\hline $\begin{array}{l}\text { DL60 +10\% } \\
\text { meta +10\% } \\
\text { brick2 }\end{array}$ & DL60 & 240 & 30 & 0 & 30 & 600 & 200 & $20.0 \%$ \\
\hline $\begin{array}{l}\text { DL60+ } \\
\mathbf{2 8 . 5 \%} \text { brick2 }\end{array}$ & DL60 & 214.5 & 0 & 0 & 85.5 & 600 & 200 & $28.5 \%$ \\
\hline $\begin{array}{l}\text { CL90+ 20\% } \\
\text { brick1 }\end{array}$ & CL90 & 240 & 0 & 60 & 0 & 600 & 300 & $20.0 \%$ \\
\hline $\begin{array}{l}\text { CL90 + 20\% } \\
\text { brick2 }\end{array}$ & CL90 & 240 & 0 & 0 & 60 & 600 & 300 & $20.0 \%$ \\
\hline
\end{tabular}




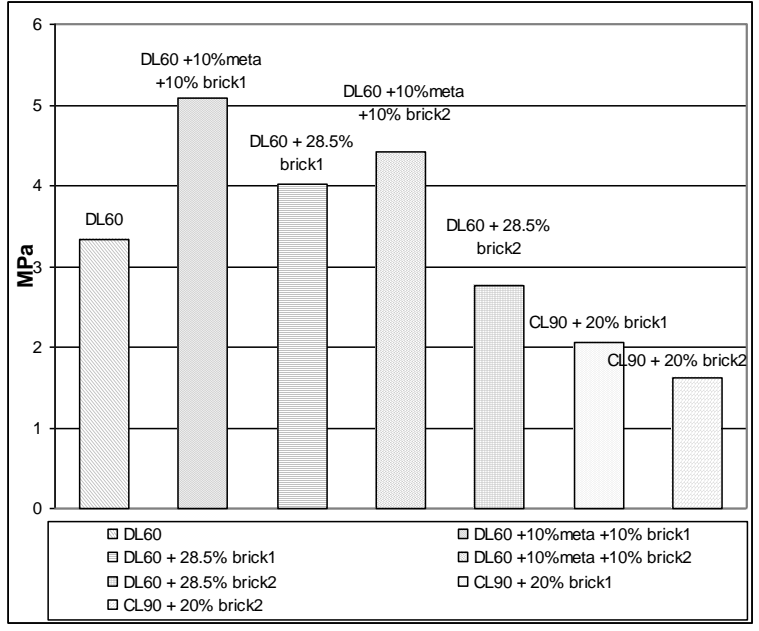

Fig. IV. Compressive strengths of binders with various additives.

Proportions of mix compositions are summarized in Table III.

Results of the first experimental stage are shown in Fig. 3. It shows that CL80 lime has the lowest ability to react with hydraulic additions, which is due to its lower amount of active $\mathrm{Ca}(\mathrm{OH})_{2}$ [15]. Result of CL90 with $20 \%$ metakaolin shows good result (4.55 MPa) which is about the same as in similar researches [10]. The best result is generated by DL60 lime with $40 \%$ metakaolin addition $-9.98 \mathrm{MPa}$. The results of second experimental stage are summarized in Fig. 4. As shown, none of the compositions can match the best results of the first stage. It can be seen that both ground brick additives have little hydraulic activity, and works more as a microfiller. Of course it can be beneficial to supplement lime or some more active hydraulic additive not compromising the result, but in this particular research binder with the best compressive strength is needed, so for furtherer research DL60 lime with $40 \%$ metakaolin is chosen.

\section{B. Producing Biocomposites}

Three compositions of hemp shives and hydraulic lime binder (DL60 with metakaolin) were produced, mix proportions are summarized in Table IV. The most commonly applied hemp/lime proportion by weight was used in mix $2 .-0.38,[14]$, the other two are with lower and higher ratio, to test the effect of density on compressive strength and thermal conductivity.

As can be seen from Fig. 5, which is forcedeformation diagram for compositions from Table IV - increasing the amount of hemp shives above 0.38

TABLE IV

\section{BIOCOMPOSITE CHARECTARISTICS}

\begin{tabular}{|l|l|l|c|l|}
\hline Nr. & $\begin{array}{l}\text { Hemp/ } \\
\text { binder } \\
\text { ratio }\end{array}$ & $\begin{array}{l}\text { Density, } \\
\mathrm{kg} / \mathrm{m} 3\end{array}$ & $\begin{array}{l}\text { Compressive } \\
\text { strength, MPa }\end{array}$ & $\begin{array}{l}\text { Thermal } \\
\text { conductivity } \\
\lambda, \mathrm{W} / \mathrm{m} 8 \mathrm{k}\end{array}$ \\
\hline $\mathbf{1 .}$ & 0.31 & 337 & 0.222 & 0.0867 \\
\hline $\mathbf{2 .}$ & 0.38 & 328 & 0.221 & 0.0757 \\
\hline $\mathbf{3 .}$ & 0.47 & 312 & 0.179 & 0.1010 \\
\hline
\end{tabular}

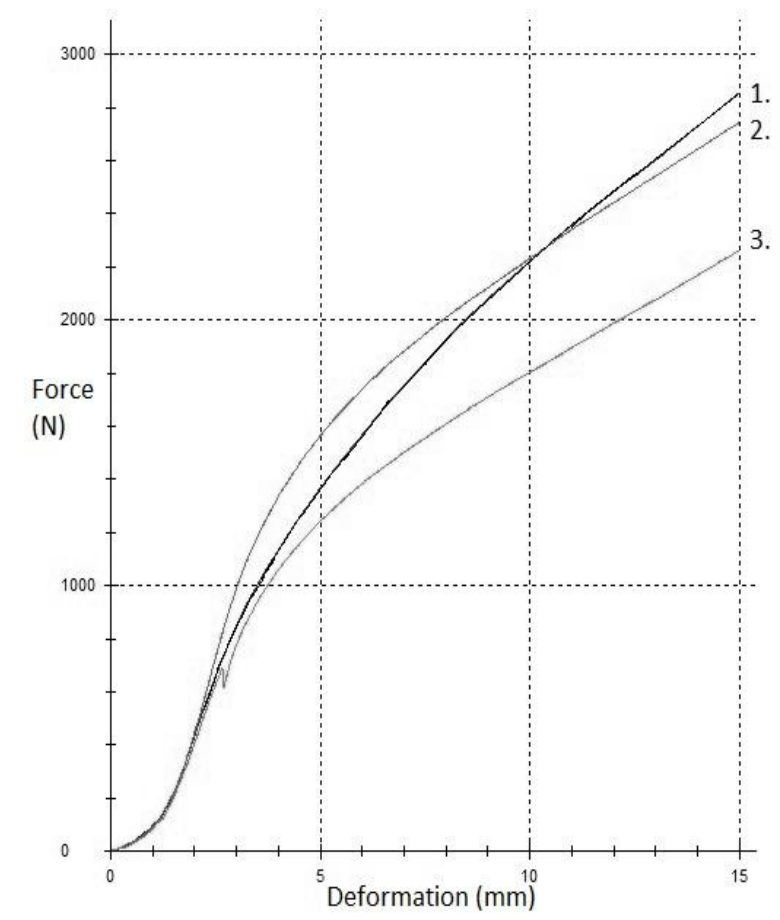

Fig. V. Force-deformation diagram of biocomposites

has a direct negative effect on compressive strength, as for lowering below 0.38 does not show any effect. This trend can also be seen in Table IV where applied force at $10 \%$ deformation is given. It can be explained that proportion of 0.38 is very optimal for this shive granulometry as binder can cover all shives, thus giving the required strength. Increasing the amount of shives creates spots with no binder, which leads to lower compressive strength, but increasing the amount of binder a little does not give notable strength rise, as area of contact zone between hemp shives does not significantly change. Of course, there is a proportion after which the compressive strength rises, but it also has its effect on thermal conductivity. If compared to other studies, then compressive strength of around 0.2 $\mathrm{MPa}$ for $330 \mathrm{~kg} / \mathrm{m}^{3}$ density samples is considered good and acceptable for using as thermal insulation material in low-rise buildings [16].

The results of thermal conductivity coefficient $\lambda$ are also given in Table IV, and are compared to results of previous tests in Fig. 6. As can be seen from the figure, all three samples stand very close to exponential trendline, which means that all three mixes made are comparable to the ones tested before, whose results are considered as acceptable and usable in further development of thermal insulation biocomposites [16].

\section{CONCLUSIONS}

1. As the most suitable binder for biocomposites DL60 lime with 40\% metakaolin addition was found, as it gave the highest compressive strength value.

2. CL90 lime showed lower results with metakaolin then DL60 lime, but it performed better than 
CL80 lime, because of higher amount of active lime.

3. Ground brick showed little hydraulic activity, and could only be used to replace lime for cost saving, but could not increase compressive strength significantly enough to be used in further research.

4. The optimal hemp/binder ratio for this granulometry of shives is 0.38 , as more shives decreases compressive strength, and less does not increase it noticeably.

5. The achieved result - hemp/lime biocomposite with compressive strength of about $0.2 \mathrm{MPa}$ for $330 \mathrm{~kg} / \mathrm{m} 3$ density is acceptable for use as selfbearing thermal insulation material in low-rise buildings.

6. The thermal conductivity coefficients that were achieved stand very close to the exponential trendline of results from previous studies, which means that they are compatible and usable.

7. The aim of this study was achieved as optimal natural binder composition was elaborated and sustainable thermal insulation biocomposites were created.

\section{REFERENCES}

[1] Bruijn P. "Mechanical Properties using both Shives and Fibres," 2008. Faculty of Landscape Planning, Hortculture and Agricultural Sciences, Alnarp. [Online]. Available: http://lup.lub.lu.se/luur/download?func=downloadFile\&record OId=1717272\&fileOId=1717289 [Accessed: Mar. 1, 2013]

[2] Tracking Indrustrial Energy Efficiency and $\mathrm{CO} 2$ Emissions. France: IEA, 2007.

[3] Klavs G. "Siltumnīcefekta gāzu emisijas Latvijā: emisiju avoti un to ietekmējošie faktori." Slideshare.net [Online]. Available: http://www.slideshare.net/SorosaFonds/g-klavs-15949447 [Accessed: Mar. 1, 2013]

[4] Bushbridge R. "Hemp-clay: an initial investigation into the thermal, structural and environmental credentials of monolithic clay and hemp," 2009. Graduate School at the Centre for Alternative Technology [Online]. Available:
http://gse.cat.org.uk/public_downloads/research/hemp/Ruth_B usbridge.pdf [Accessed: Mar. 1, 2013]

[5] Glaeser E.L., Kahn M.E., Wang R., Zheng S. "The Greenness of China," 2009. Harward Kennedy school [Online]. Available: http://www.hks.harvard.edu/mrcbg/heep/papers/HEEP\%20Discussion\%2012.pdf [Accessed: Mar. 1, 2013]

[6] Lawrence R. M. H. „A study of carbonation in non-hydraulic lime mortars." University of Bath" [Online]. Available: http://opus.bath.ac.uk/394/ [Accessed: Mar. 1, 2013]

[7] Strozs M., Sahmenko G. "Use of straw-clay material in walls," 3rd international Civil Engineering conference, building materials 1, pp. 84-90, 2011

[8] Wilkinson S "A Study of the Moisture Buffering Potential of Hemp in Combination with Lime and Clay-Based Binders." 2009. Graduate School at the Centre for Alternative Technology [Online]. Available: http://gse.cat.org.uk/public_downloads/research/hemp/Simon Wilkinson.pdf [Accessed: Mar. 1, 2013]

[9] Cerny R., et al. "Effect of pozzolanic admixtures on mechanical, thermal and hygric properties of lime plasters," 2006. Construction and Building Materials 20, p. 849-857

[10] Vejmelkova E., et al. „Application of burnt clay shale as pozzolan addition to lime mortar," 2012. Cement \& Concrete Composites 34, p. 486-492

[11] Wegian F.M., AlSaeid H.M., Alnaki A.A. "Effect of lime and fly ash on the strength of cement composite mortars." Australian Journal of Structural Engineering 12, 2011 p. 47-56

[12] Edwards D.D. "Pozzolanic properties of glass fines in lime mortar." Advances in Applied Ceramics, 2007 p. 309-313

[13] Miskin N. "The Carbon Sequestration Potential of Hempbinder." Graduate School at the Centre for Alternative Technology [Online]. Available: http://gse.cat.org.uk/public_downloads/research/hemp/N_Mis kin.pdf [Accessed: Mar. 1, 2013

[14] Ip K., Miller A. "Life cycle greenhouse gas emissions of hemp-lime wall constructions in the UK." Resources, Conservation and Recycling 69, 2012 p. 1-9

[15] Vejmelkova E., et al. Mechanical, fracture-mechanical, hygric, thermal, and durability properties of lime-metakaolin plasters for renovation of historical buildings // In: Construction and Building materials $31,2012-$ p. 22-28

[16] Sinka M., Korjakins A., Sahmenko G. "The use of hemp shives with hydraulic lime binder in insulation materials" [Online]. Available: http://aurora.turiba.lv/bti/Editor/ Manuscript/Proceeding/Proceeding.pdf [Accessed: Mar. 1, 2013]

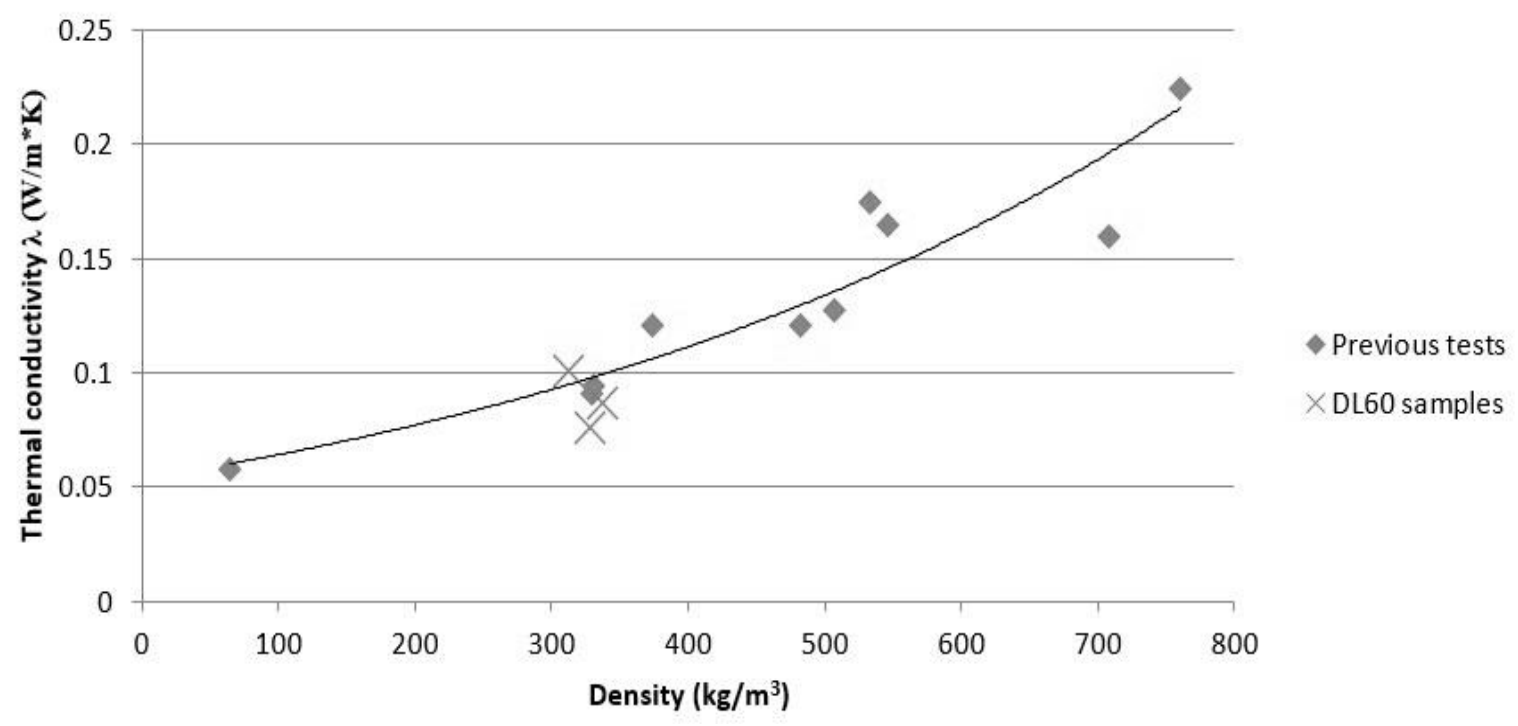

Fig. VI. Thermal conductivity correlation with density 